\title{
Regulation of adductor muscle growth by the IGF-1/AKT pathway in the triploid Pacific oyster, Crassostrea gigas
}

\author{
Eun-Young $\mathrm{Kim}^{1}$ and Youn Hee $\mathrm{Choi}^{1,2^{*}}$ (D)
}

\begin{abstract}
We investigated the insulin-like growth factor 1 (IGF-1)/AKT signaling pathway involved in muscle formation, growth, and movement in the adductor muscle of triploid Pacific oyster, Crassostrea gigas. Large and small triploid oysters (LTS and STs) cultured under identical conditions were screened, and the signaling pathways of individuals with superior growth were compared and analyzed. mRNA and protein expression levels of actin, troponin, tropomyosin, and myosin, proteins important in muscle formation, were higher in LTs compared with STs. Expression levels of IGF-1, IGF binding protein (IGFBP), and IGFBP complex acid-labile subunit were also higher in LTs compared with STs. Phosphorylation of the IGF receptor as well as that of AKT was high in LTs. In addition, the expression of phosphomammalian target of rapamycin and phospho-glycogen synthase kinase $3 \beta$ was increased and the expression of Forkhead box $\mathrm{O} 3$ was decreased in LTs. Therefore, we suggested that the IGF-1/AKT signaling pathway affects the formation, growth, and movement of the adductor muscle in triploid oysters.
\end{abstract}

Keywords: Triploid oyster, Adductor muscle, Muscle growth, Protein synthesis, Protein degradation

\section{Background}

The triploid Pacific oyster Crassostrea gigas was first reported by Stanley et al. (1981) and commercialized on the West Coast of America in 1985 (Allen et al. 1989). At present, it is produced by crossing diploid female and tetraploid male hybrids (Guo et al. 1996), and this method is being applied to various oysters. Triploid oysters consume less energy during maturity because they do not develop germ cells. As a result, growth is faster because more energy can be used to grow somatic cells compared with diploid oysters (Allen and Downing 1986; Nell 2002; Nell and Perkins 2005). However, the signaling pathway responsible for this growth has not yet been elucidated.

Activation of the adductor muscle, i.e., muscle activity, is associated with oyster feeding behavior, which directly affects oyster growth (Hopkins 1936). Muscles are divided into striated muscles, such as skeletal and cardiac

\footnotetext{
* Correspondence: unichoi@pknu.ac.kr

${ }^{1}$ Institute of Fisheries Sciences, Pukyong National University, Busan 46041, Republic of Korea

${ }^{2}$ Department of Marine Bio-Materials and Aquaculture, Pukyong National University, Busan 48513, Republic of Korea
}

muscles, which are regularly arranged, and non-striated muscles, including smooth muscle, which make up the vessels, respiratory system, and stomach. The adductor muscle of the oyster is a typical striated muscle, which contracts and relaxes through the action of actomyosin according to the cytosolic concentration of calcium. Actomyosin is composed of actin and myosin, and troponin (T, C, I) and tropomyosin are required for their binding and formation (Kuo and Ehrlich 2015). Therefore, in this study, the mechanism of the production and activity of the adductor muscle, which is most closely related to oyster growth, was confirmed by evaluating the expression of actin, troponin, and tropomyosin, which affect the formation of actomyosin.

Muscles adapt and change according to functional needs (Rennie et al. 2004). If there is a load, muscle mass increases. However, if there is no load or the muscle is not used, muscle mass will decrease. When muscle growth is active, the roles of growth hormone $(\mathrm{GH})$ and insulin-like growth factor 1 (IGF-1) are important (Velloso 2008). GH binds to the $\mathrm{GH}$ receptor (GHR) and regulates various signals related to growth. GHR is ubiquitously expressed in various tissues to mediate the action of $\mathrm{GH}$, and $\mathrm{GH}$

(c) The Author(s). 2019 Open Access This article is distributed under the terms of the Creative Commons Attribution 4.0 International License (http://creativecommons.org/licenses/by/4.0/), which permits unrestricted use, distribution, and reproduction in any medium, provided you give appropriate credit to the original author(s) and the source, provide a link to the Creative Commons license, and indicate if changes were made. The Creative Commons Public Domain Dedication waiver (http://creativecommons.org/publicdomain/zero/1.0/) applies to the data made available in this article, unless otherwise stated. 
increases the expression of IGF-1 in most tissues (Frick et al. 1998; D’Ercole et al. 1984; Gosteli-Peter et al. 1994; Jorgensen et al. 2006). Unlike GH and GHR, IGF-1 expression is stable and does not change significantly during the day (Buckway et al. 2001; Velloso 2008). Therefore, it can be used as a factor to measure muscle growth.

Muscle hypertrophy occurs when the rate of protein synthesis exceeds the rate of protein degradation (Schiaffino et al. 2013). The IGF-1/protein kinase B (also known as AKT) signaling pathway, which is activated upon IGF-1 recognition by the IGF receptor (IGF-1R), is the most representative mechanism of muscle mass increase. IGF-1 signaling promotes muscle growth via increased protein synthesis and inhibition of protein degradation (Schiaffino and Mammucari 2011). IGF-1/AKT signaling mediates protein degradation by modulation of muscle atrophy F-box (MAFbx), muscle ring finger 1 (MURF1), and microtubule-associated protein 1 light chain 3 (LC3) via Forkhead box O3 (FoxO) (Manning and Cantley 2007). IGF-1/AKT signaling also promotes protein synthesis via mammalian target of rapamycin (mTOR) and glycogen synthase kinase (GSK)-3 $\beta$. Confirmation of the expression of each of these factors will confirm that the growth of triploid oysters is dependent on IGF-1/AKT signaling, as has been shown in mammals and other mollusks.

In this study, we analyzed the IGF-1/AKT signaling pathway and its involvement in the growth of triploid oysters and confirmed the relationship between the expression of actin and troponin, which are involved in muscle formation in the triploid oyster.

\section{Methods}

\section{Sampling and identification of the triploid oyster}

Triploid oysters were collected at a farm in Taeangun, Republic of Korea (latitude 36.903367, longitude 126.26489), in January and February of 2017. A total of 60 oysters were collected and separated into large and small triploid oysters (LTs and STs, respectively). Since there is no standardized method for classifying oysters, this study divided them according to the following criteria. LTs selected samples that meet the three conditions as shown in Fig. 1. First, both STW and TW of oysters are higher than average. Second, both shell length and shell height of oysters are above average. Third, shell width and shell length of oysters are above average. When the three conditions were satisfied, they were classified as LTs and vice versa as STs. The adductor muscle was isolated, and $0.5 \mathrm{~g}$ of each muscle was subdivided, frozen in liquid nitrogen, and stored at $-70^{\circ} \mathrm{C}$.

Triploidy was confirmed as described previously (Allen 1983) with minor modifications. Plasma was collected from 10 of the collected samples, added to $0.7 \mathrm{~mL}$
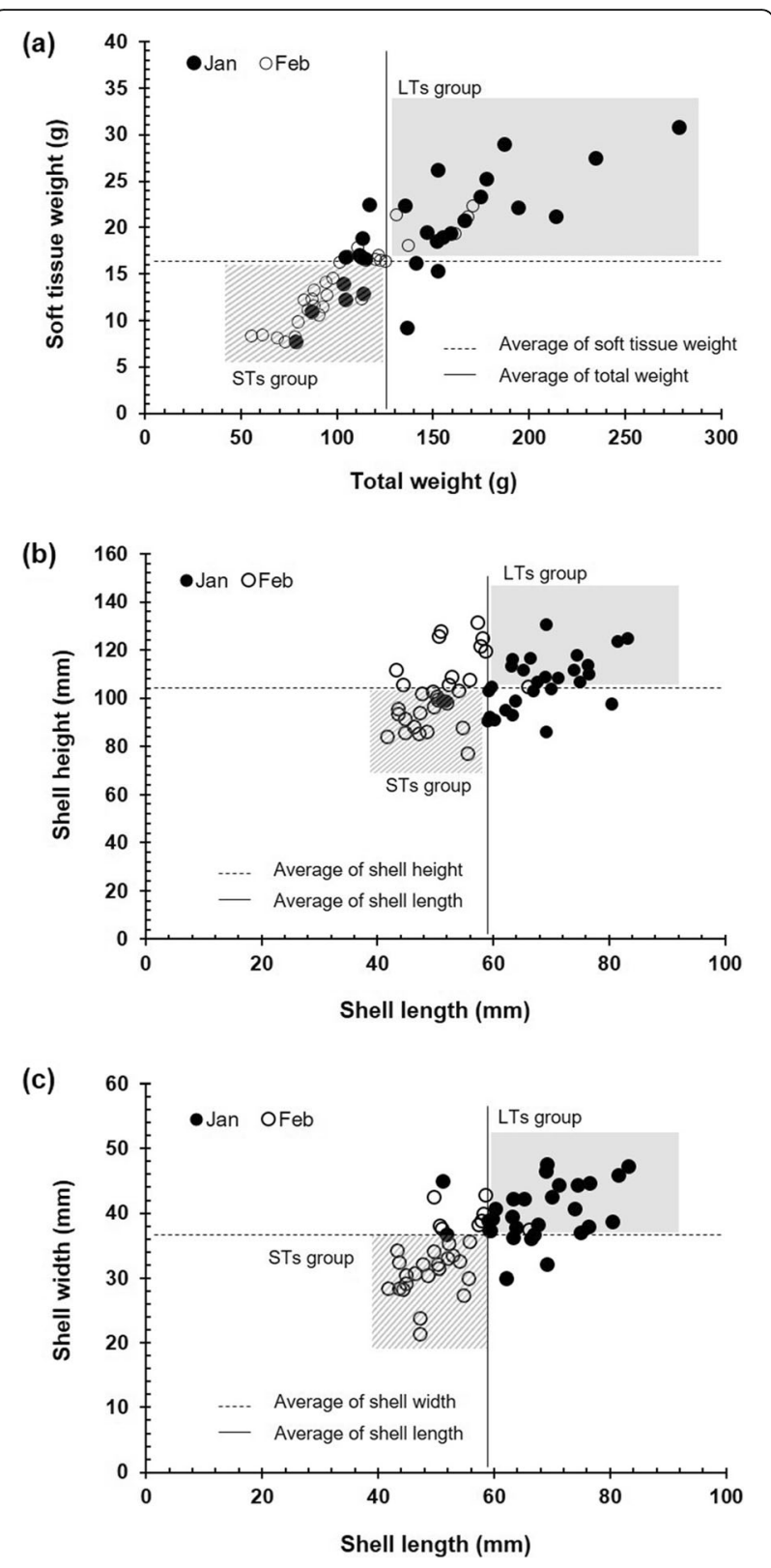

Fig. 1 Morphological correlation of the triploid oyster, Crassostrea gigas. a Soft tissue weight (STW) according to total weight (TW). b Shell height according to shell length. c Shell width according to shell length. Large triploids (LTS), shaded areas inside the graph; small triploids (STs), hatched area inside the graph. $n=60$

ethanol, and stored at $-20^{\circ} \mathrm{C}$ for more than $4 \mathrm{~h}$. After removing the supernatant by centrifugation $(3000 \mathrm{rpm}$, $10 \mathrm{~min}$ ), it was washed three times with phosphatebuffered saline. Samples were stained with propidium iodide for $30 \mathrm{~min}$ at room temperature and measured using a flow cytometer (BD Accuri C6, BD Biosciences, Franklin Lakes, NJ, USA). Ten diploid oysters were collected from the southern Korean sea for DNA verification compared with the triploid oyster. 
CDNA synthesis and reverse-transcription polymerase chain reaction (RT-PCR)

The adductor muscle $(0.5 \mathrm{~g}$, LTs $n=3$; STs $n=3)$ was pulverized by adding $1 \mathrm{~mL}$ Trans-Zol UP (TransGen Biotech, Beijing, China), and total RNA was extracted using TransZol UP according to the manufacturer's instructions. cDNA was synthesized from $2 \mu \mathrm{g}$ total RNA using the PrimeScript first strand cDNA synthesis kit (TaKaRa Bio, Otsu, Japan) according to the manufacturer's instructions. RT-PCR was performed using Emerald Amp GT PCR Master Mix (TaKaRa Bio). The primers (targeting elongation factor $1 \alpha$, IGF-1, IGF-IR, IGF binding protein complex acid-labile subunit [IGF-ALS], actin, myosin, troponin $\mathrm{T}$, troponin I, and tropomyosin) and reaction parameters (denaturation, $95^{\circ} \mathrm{C}, 30 \mathrm{~s}$; annealing, indicated temperature, $30 \mathrm{~s}$; elongation, $72{ }^{\circ} \mathrm{C}, 30 \mathrm{~s}$ ) used for RT-PCR are shown in Table 1. Primers were designed based on the gene sequences of $C$. gigas obtained from NCBI GenBank. The PCR products were confirmed by $1 \%$ agarose gel electrophoresis.

\section{Protein purification and western blotting}

Total protein extraction was performed by adding $1 \mathrm{~mL}$ radioimmunoprecipitation buffer to $0.5 \mathrm{~g}$ adductor muscle (LTs, $n=3$; STs, $n=3$ ). The homogenized tissue was centrifuged $\left(12,000 \mathrm{rpm}, 10 \mathrm{~min}, 4^{\circ} \mathrm{C}\right)$ and the supernatant used. Protein quantification was performed using the bicinchoninic acid assay, and bovine serum albumin (BSA) was used as a standard. Proteins $(2 \mu \mathrm{g} / \mu \mathrm{L})$ were subjected to gel electrophoresis using a $12 \%$ polyacrylamide gel and transferred to a polyvinylidene fluoride membrane for immunoblotting. Membranes were blocked with Tris-buffered saline containing $0.1 \%$ Tween-20 (TBST) and 1\% BSA at room temperature for at least $2 \mathrm{~h}$. The membranes were then incubated with the primary and secondary antibodies at room temperature for at least $1 \mathrm{~h}$, followed by detection with enhanced chemiluminescence western blotting reagents (Santa Cruz Biotechnology, Inc., Santa Cruz, CA, USA). Between each step, two washes with TBST were performed. The following primary antibodies and the anti-mouse secondary antibody were obtained from Santa Cruz Biotechnology, Inc., and diluted 1:1000: IGF-1, IGF binding protein (IGF-BP)3, IGF-1R, phosphorylated (p)-IGF-1R, AKT, p-AKT, mTOR, p-mTOR, FoxO, p-FoxO, GSK3 $\beta$, p-GSK3 $\beta$, eukaryotic translation initiation factor $4 \mathrm{E}$ binding proteins 1 (4EBP1), Ribosomal protein S6 kinase beta 1 (p70S6K1), MAFbx, MURF1, LC3, eukaryotic translation initiation factor 2B (elF2B), nebulin, neural Wiskott-Aldrich syndrome protein (N-WASP), peroxisome proliferatoractivated receptor $\gamma$ coactivator (PGC) $1 \alpha$, troponin I, troponin $\mathrm{T}$, and $\mathrm{F}$-actin antibodies.

\section{Statistical analysis}

RT-PCR and western blotting results were analyzed using GeneTools software (version 4.03; Syngene, Cambridge, UK). Data are presented as means \pm standard

Table 1 Primer sequences for RT-PCR, amplicon size, PCR efficiencies, and GenBank accession numbers of the genes evaluated in this study. Primers were designed based on Crassostrea gigas sequences. F forward primer, $R$ reverse primer, AT annealing temperature

\begin{tabular}{|c|c|c|c|c|c|}
\hline Gene & Accession number & Sequence $\left(5^{\prime}-3^{\prime}\right)$ & Amplicon size (bp) & PCR cycle & AT $\left({ }^{\circ} \mathrm{C}\right)$ \\
\hline \multirow[t]{2}{*}{ EF1a } & AB122066.1 & (F) CCACTGGCCATCTCATTTAC & 393 & 20 & 60 \\
\hline & & (R) TGTTGACACCAATGATGAGC & & & \\
\hline \multirow[t]{2}{*}{ IGF-1 } & XM_011417420.2 & (F) ATGGTTTGCCCTGTCTTGAG & 336 & 25 & 55 \\
\hline & & (R) AGATCCTTTCTTCTTGCGGC & & & \\
\hline \multirow[t]{2}{*}{ IGF-IR } & AJ535669.1 & (F) TGAGGAGGGTGATGAGGATA & 375 & 25 & 55 \\
\hline & & (R) ATTGCACTGTAGGGATTGGA & & & \\
\hline \multirow[t]{2}{*}{ IGF-ALS } & XM_011417921.2 & (F) ATGTCCAAAACAATGCGTCT & 359 & 25 & 55 \\
\hline & & (R) TCCAAAACGCGTAACTTITC & & & \\
\hline \multirow[t]{2}{*}{ Actin-2 } & EKC31894.1 & (F) TTTCGCCGGAGATGATGCCC & 434 & 20 & 60 \\
\hline & & (R) TGGGGACAGTGTGGGTGACA & & & \\
\hline \multirow[t]{2}{*}{ Myosin } & EKC37566.1 & (F) TTGGGTGGTGAGGCACAGG & 544 & 20 & 60 \\
\hline & & (R) TTTGCTGAGCTGGCGTTGGA & & & \\
\hline \multirow[t]{2}{*}{ Troponin T } & XM_020062462.1 & (F) AGGAACGCGAGAAAGAACAA & 375 & 20 & 60 \\
\hline & & (R) TGATCCTCTGGGACAGGAAG & & & \\
\hline \multirow[t]{2}{*}{ Troponin I } & XM_011455869.2 & (F) CCACCCTGGAGGAAGAAGTC & 187 & 20 & 60 \\
\hline & & (R) AAATTGCCACGGAAATCTGA & & & \\
\hline \multirow[t]{2}{*}{ Tropomyosin } & NM_001308906.1 & (F) GCCATGAAAATGGAGAAGGA & 381 & 20 & 60 \\
\hline & & (R) GGCGTTATTGAGGTTITCCA & & & \\
\hline
\end{tabular}


deviation and were analyzed using Statistical Package for Social Sciences, version 10.0 (SPSS, Inc., Chicago, IL, USA). Statistical analysis was performed using Duncan's multi-range test followed by one-way analysis of variance. $p<0.05$ was considered to indicate statistical significance.

\section{Results}

\section{Growth characteristics and identification of triploid oysters}

In total, 60 triploid oysters collected from Taean were classified as LTs and STs depending on their size (shell length, SL; shell height, SH; shell width, SW) and weight (total weight, TW; soft tissue weight, STW). The TW of the triploid oysters ranged from 55.34 to $277.75 \mathrm{~g}$, with a mean of $125.40 \pm 43.50 \mathrm{~g}$. The STW ranged from 7.72 to $30.87 \mathrm{~g}$, with a mean of $16.55 \pm 5.54 \mathrm{~g}$ (Fig. 1a). Fatness ranged from 6.80 to $19.30 \%$, with a mean of $13.34 \pm$ $2.19 \%$. The growth rate of $\mathrm{SL} / \mathrm{SH}$, ranged from 0.45 to 0.88 , while the growth rate of SW/SL, ranged from 2.20 to 4.00 (Fig. 1b, c), with means of $0.63 \pm 0.09$ and $2.89 \pm$ 0.38 , respectively. In this study, 10 individuals were selected as LTs or STs with a satisfactory combination of STW/TW, SH/SL, and SW/SL and were used to analyze the growth signals of muscles according to their size (Fig. 1, LTs, shaded areas inside the graph; STs, hatched areas inside the graph).

Flow cytometry revealed that the average amount of DNA in diploid oysters, which were used as a control, was $245 \pm 38.91$, and the average amount of DNA in triploid oysters was $368 \pm 23.23$ (Fig. 2). The DNA content ratio of diploid to triploid oysters was $1: 1.5$, confirming that the oysters used in this study were triploid.

\section{Expression of muscle proteins according to triploid oyster} size

The differences in mRNA and protein expression of actin, myosin, troponin, and tropomyosin, which are integral in muscle formation, were examined. The mRNA expression of actin, troponin, and tropomyosin was 1.43-2.22-fold higher in LTs than in STs (Fig. 3a), while the protein expression of actin, troponin $\mathrm{T}$ and $\mathrm{I}$, and tropomyosin was 1.18-3.60-fold higher in LTs than in STs (Fig. 3b). Thus, the expression of mRNAs and proteins responsible for muscle formation, contraction, and relaxation varied depending on the size of the oyster.

\section{Expression of IGF-1 according to triploid oyster size}

The expression level of IGF-1 mRNA was three times higher in LTs than in STs (Fig. 4a). IGF-ALS, which binds IGF-1 and IGF-IR and initiates IGF-1 signaling, also showed high mRNA expression in LTs (Fig. 4a).

IGF-1 protein expression, as well as that of IGF-BP and IGF-IR, was also higher in LTs compared with STs (Fig. 4b). In particular, the level of p-IGF-IR was significantly increased in LTs compared with STs. To investigate the IGF-1/AKT signaling pathway involved in the synthesis and degradation of muscle proteins, the levels of AKT1 and p-AKT were assessed. The level of p-AKT was 1.29-fold higher in LTs compared with STs.

\section{Mechanism of protein synthesis}

The expression of mTOR, GSK3 $\beta$, 4EBP1, and p70S6K1, elements downstream of IGF-1/AKT signaling associated with protein synthesis, were confirmed (Fig. 5a). Phosphorylation of mTOR was 1.46-fold higher in LTs compared with STs. Consequently, the expression level of 4EBP1 was decreased and that of p70S6K1 increased. The
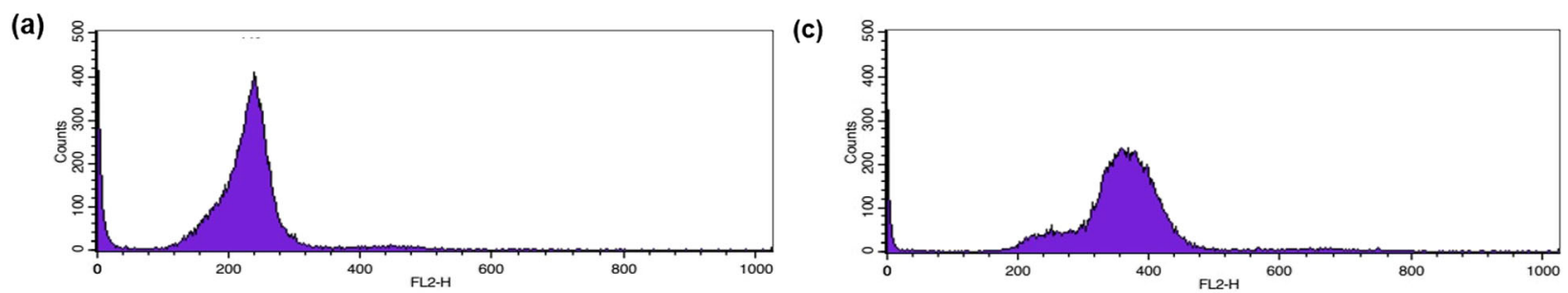

(b)

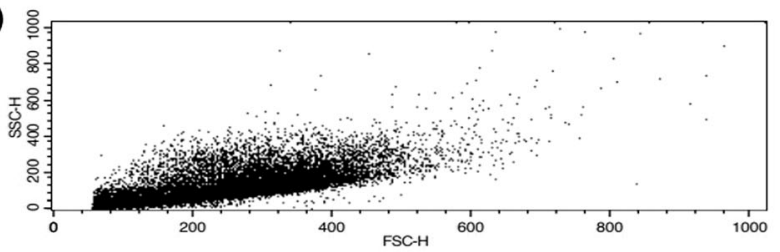

(d)

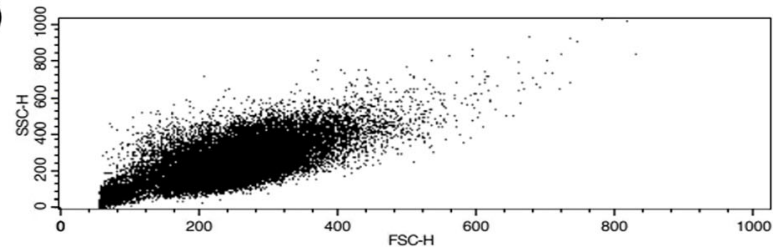

Fig. 2 Flow cytometry analysis showing the DNA histograms (top graph) and scatter diagrams (bottom graph) of propidium iodide (red fluorescence, FL2-H)-labeled oysters. a, b Diploid oysters. c, d Triploid oysters. Diploid oysters were used as a control for the amount of DNA. FSC$\mathrm{H}$, forward side scatter-height; SSC-H, side scatter-height 

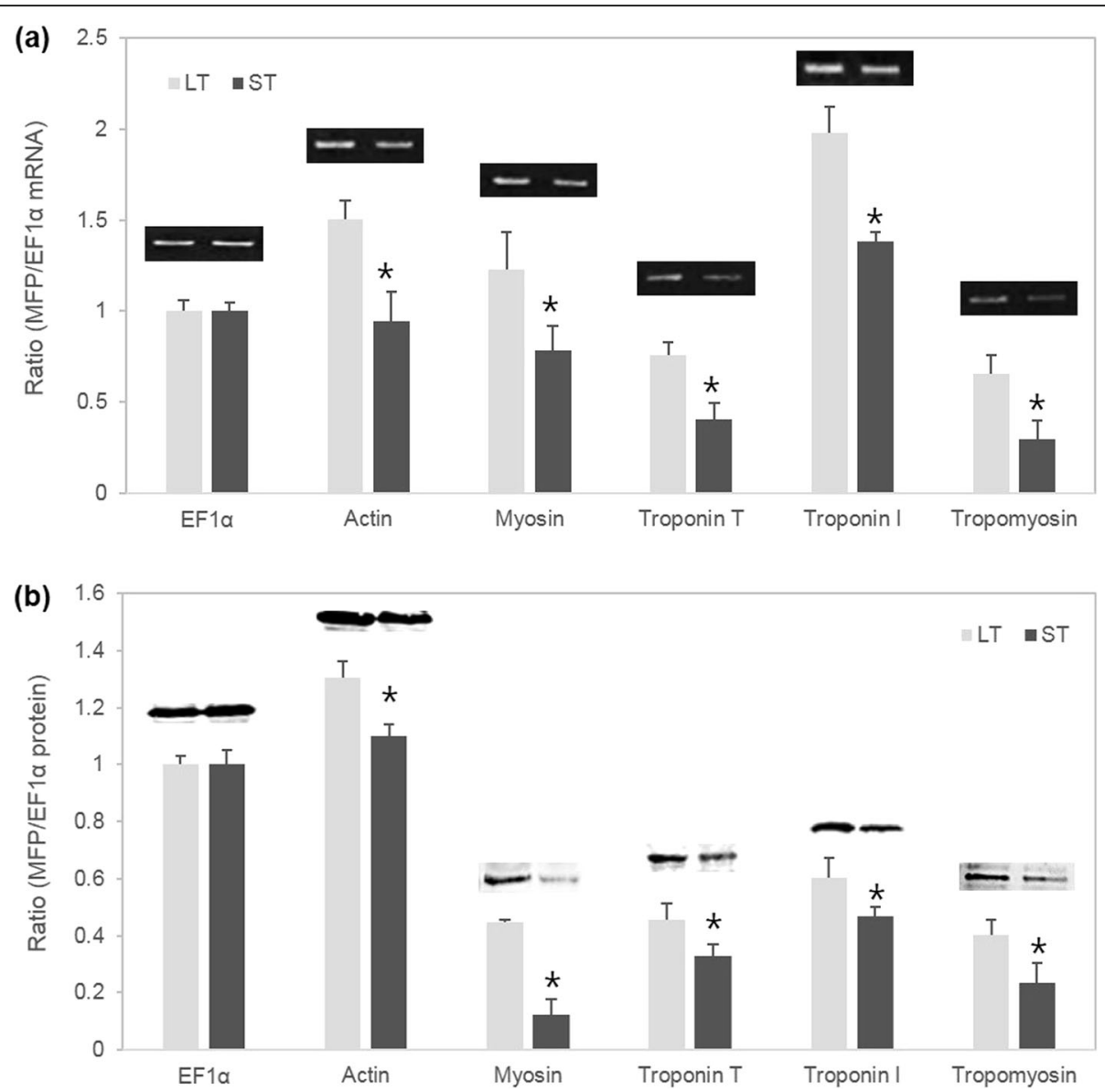

Fig. 3 Expression of muscle-forming proteins according to triploid oyster size. a mRNA expression $(n=5)$. b Protein expression $(n=3)$. ${ }^{*} p<0.05$ vs. LT. LT, large triploid; ST, small triploid; MFP, muscle-forming proteins

expression of p-GSK3 $\beta$ was also 1.37-fold higher in LTs compared with STs. This increased protein synthesis occurred via inhibition of eIF2B expression.

\section{Mechanism of protein degradation}

The expression of FoxO, an IGF-1/AKT downstream effector related to protein degradation, was increased 2.64-fold in STs compared with LTs (Fig. 5b), in contrast to $\mathrm{mTOR}$ and GSK3 $\beta$. FoxO affects the function of MAFbx, MURF1, and LC3, and the expression of these proteins was decreased in LTs compared with STs. MAFbx and MURF1 are important in the degradation of muscle proteins including myosin via proteasomedependent ubiquitylation, and LC3 is involved in the autophagy-lysosome pathway.

\section{GSK3 $\beta$ and actin polymerization}

GSK3 $\beta$ increases the phosphorylation of nebulin. Nonphosphorylated nebulin has been shown to modulate $\mathrm{N}$ WASP to promote elongation and nucleation of actin filaments, thereby enhancing myofibril growth (Takano et al. 2010). Inhibition of GSK3 $\beta$ in the triploid oyster resulted in increased levels of non-phosphorylated nebulin (Fig. 5c). The expression of N-WASP was 1.34-fold higher in LTs compared with STs.

\section{PGC1a and troponin}

The expression of troponin T and I and PGC1 $\alpha$ was increased 1.87-, 1.43-, and 1.57-fold in LTs compared with STs, respectively (Figs. 3 and $5 \mathrm{c}$ ).

\section{Discussion}

Triploid oysters have been reported to grow faster than diploid oysters because they use the energy required for maturation for flesh obesity (Allen and Downing 1986; Nell and Perkins 2005). However, oyster size differs to some extent even under the same conditions. In this study, we used adductor muscles excised from triploid oysters to analyze this difference. Adductor muscle (AM) plays an important role in the influx of food and communication with the external environment. Oysters limit oxygen exchange through shell closure at low tide. AM plays an important role in regulating the opening and closing of these shells through translucent and white 

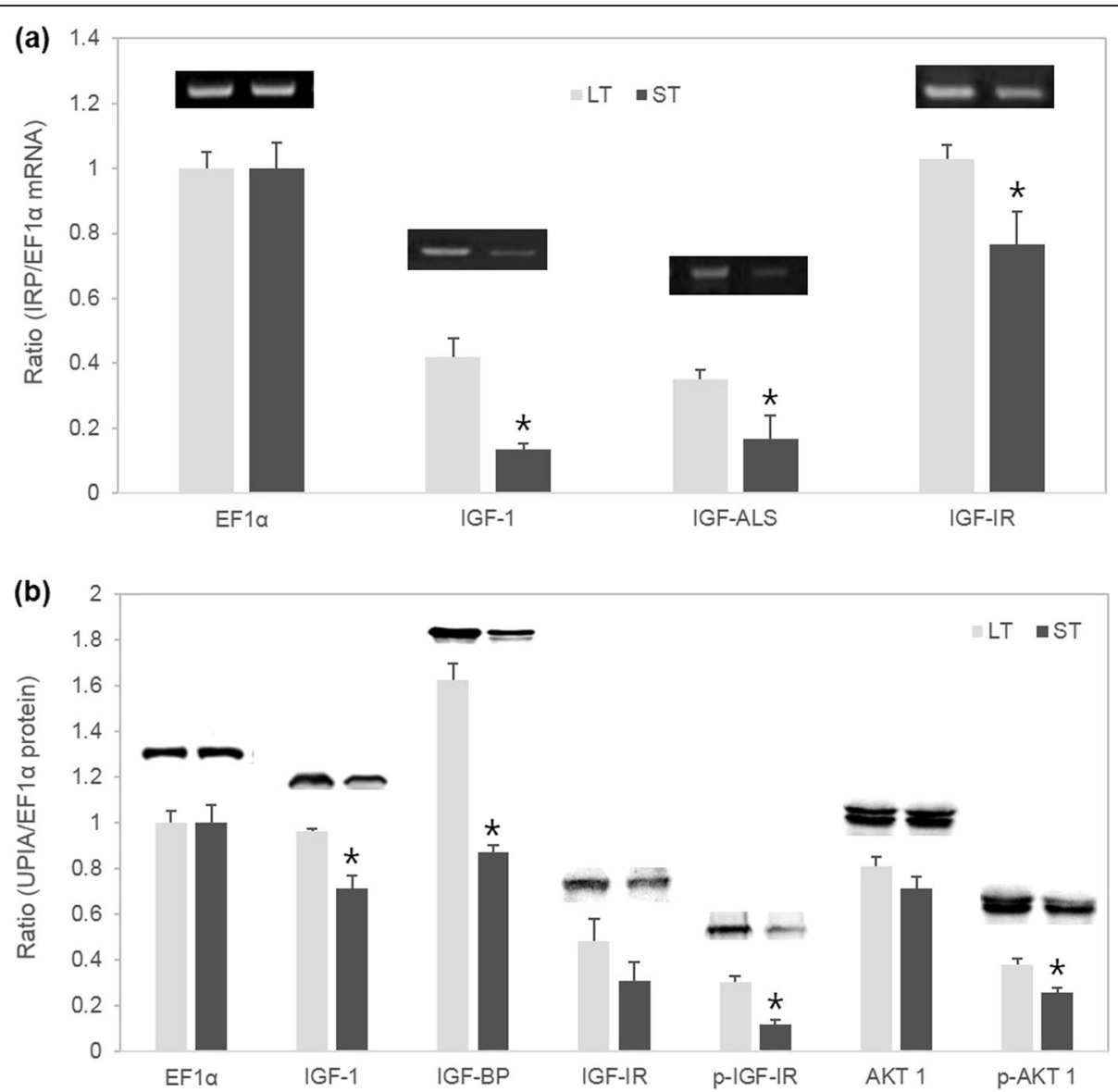

Fig. 4 Expression of upstream proteins in the IGF-1/AKT signaling pathway according to triploid oyster size. a mRNA expression $(n=5)$. b Protein expression $(n=3)$. ${ }^{*} p<0.05$ vs. LT. LT, large triploid; ST, small triploid; IRP, IGF-1 related proteins

opaque muscles. Oxygen is limited but oysters lower intracellular $\mathrm{pH}$ for survival and regulate the expression of carbohydrates, proteins, tRNA, ncRNA, and amino acid metabolism-related genes. Among them, dioxygenase, which corresponds to dietary changes in AM, is drastically reduced and maintains cysteine homeostasis in foodrestricted situations (Zhang et al. 2012; Chapman et al. 2011). AM is the main organ of oysters that perform these functions. Therefore, the formation and development of AM has a very important effect on the growth and diet of oysters. On the other hand, AM produces large amounts of melanin, and it is reported that the more melanin in the shell, the higher the dry weight of oysters (Yu et al. 2017; Hao et al. 2015; Xiao yan et al. 2003). Melanin removes free radicals and reduces damage to AM, which allows AM to open larger shells and filter out more algae to speed up growth. We examined the effects of growth factors on muscle formation and activity in the adductor muscle and analyzed related signaling pathways.

IGF-1 plays an important role in muscle growth in triploid oysters. The expression of actin, myosin, troponin, and tropomyosin, which form muscles in LT and ST adductor muscle, as well as the mRNA and protein expression of IGF-1, differed significantly. In addition, the expression of IGF-ALS and IGF-BP, which increases the half-life in combination with IGF-1 (Baxter et al. 1989), was also higher in mRNA and protein. This finding confirmed that IGF-1 affects muscle growth in LTs. In addition, the expression of cofactors required for the activity of IGF-1 in tissues was also increased, and the signaling pathway associated with IGF-1 was activated by increasing phosphorylation of IGF-1R. According to Gricourt et al. $(2003,2006)$, an insulin-like system functions when C. gigas growth is increased; in particular, mRNA and protein levels of IGF-1 and insulin receptor-related receptors are increased. Our results showed that the expression of IGF-1 was high in LTs with a high growth rate, consistent with that previous study. The regression analysis of IGF-1/EF1 $\alpha$ gene expression according to STW confirmed the significance $(p<0.05)$. This is the first report explaining the association between STW and IFG-1 gene expression in triploid oysters. 

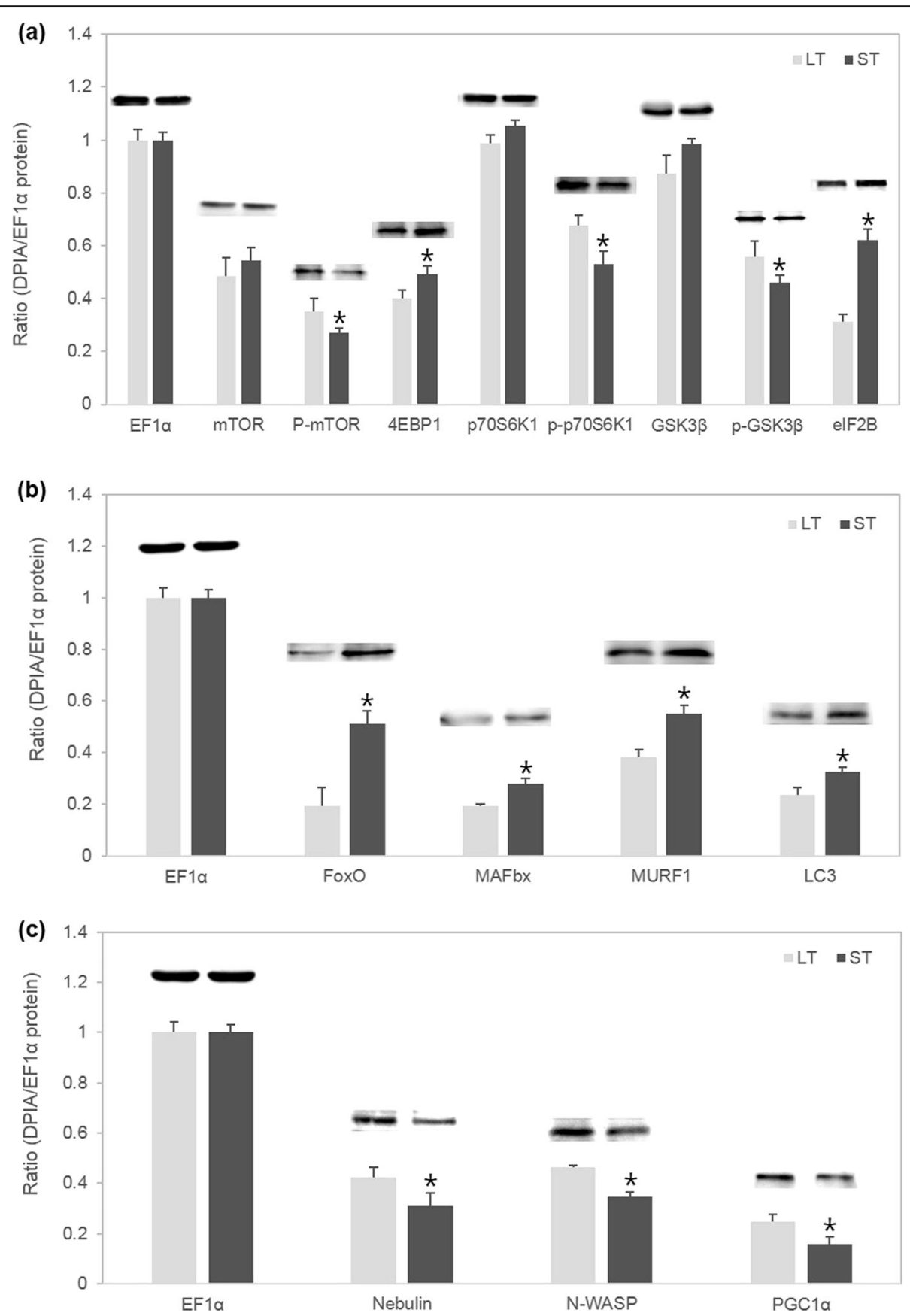

Fig. 5 Expression of downstream proteins in the IGF-1/AKT signaling pathway according to triploid oyster size. a Expression of signaling factors related to protein synthesis. $\mathbf{b}$ Expression of signaling factors related to protein degradation. $\mathbf{c}$ Expression of signaling factors related to myofibrillogenesis. $n=3 .{ }^{*} p<0.05$ vs. LT. LT, large triploid; ST, small triploid

The size-dependent increase in p-AKT suggested the possibility that IGF-1 signaling regulates protein synthesis and degradation of muscle via AKT. AKT activity has been reported to increase the activity of mTOR, which is involved in protein synthesis, and to inhibit the activation of GSK3 $\beta$, which is involved in muscle formation (Glass 2010; Miyazaki and Esser 2009; Sandri 2008; Manning and Cantley 2007; Sarbassov et al. 2005).
Furthermore, protein degradation is inhibited by inhibition of FoxO expression, which regulates MAFbx, MURF1, and LC3, which induce protein degradation (Stitt et al. 2004; Mammucari et al. 2007). The level of activated mTOR was higher, and the expression of GSK3 $\beta$ and FoxO lower, in LTs than in STs. LTs appear to increase muscle protein content by promoting synthesis and inhibiting degradation of proteins to a greater 


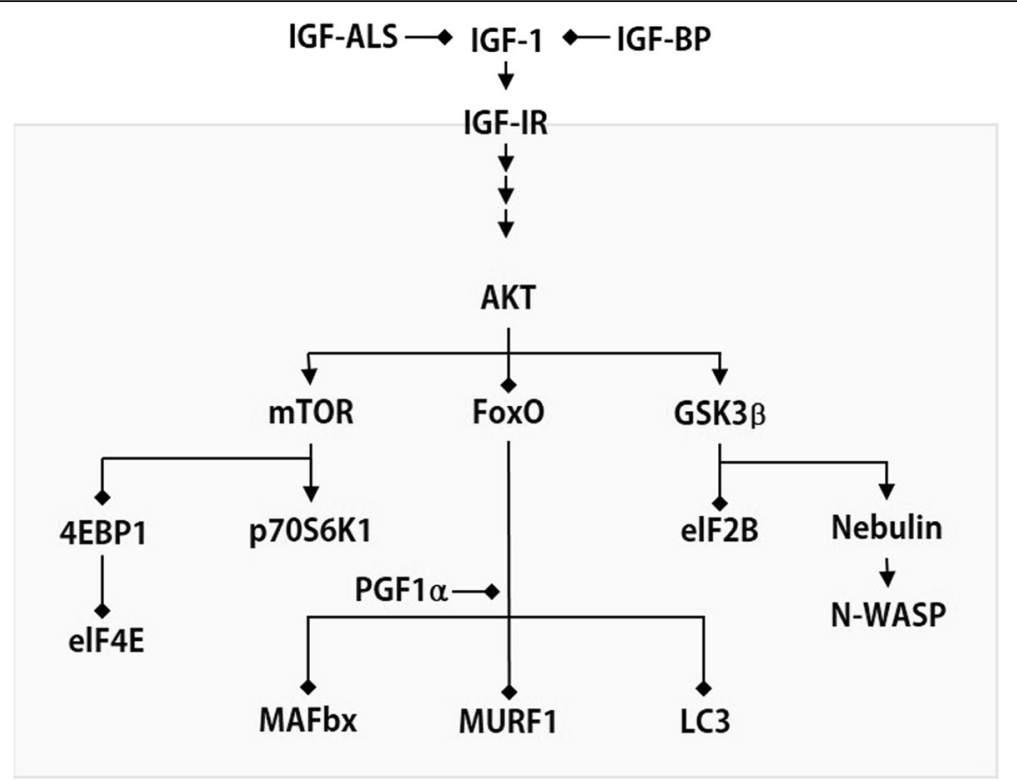

Fig. 6 IGF-1/AKT signaling pathways in adductor muscle growth and formation in triploid Pacific oyster, Crassostrea gigas

degree compared with STs. IGF-1/AKT signaling regulates muscle growth in triploid oysters by promoting protein synthesis and inhibiting degradation. In mammalian cells, PI3K/AKT signaling under hypoxic conditions has been reported to regulate glucose metabolism and apoptosis (Kim et al. 2012; Parcellier et al. 2008; Alvarez-Tejado et al. 2001). Guevelou et al. (2013) also reported increased expression of AKT under hypoxic conditions in the smooth muscle of C. gigas; however, AKT expression did not increase under hypoxic conditions in striated muscle. These results suggest that AKT, which is expressed in striated muscle of C. gigas, is involved in metabolism related to the synthesis and degradation of muscle protein rather than regulation of glucose metabolism and apoptosis.

GSK3 $\beta$, which is involved in protein synthesis, increases phosphorylation of nebulin, which results in inhibition of actin polymerization (Takano et al. 2010). In the case of adductor muscle, oyster size affects both muscle formation via protein synthesis and degradation and muscle movement via muscle relaxation. Inhibition of GSK3 $\beta$ by phosphorylation of AKT inhibited the phosphorylation of nebulin, which in turn binds to N-WASP and contributes to muscular movement (Rommel et al. 2001). The expression of nebulin and N-WASP was higher in LTs compared with STs. In particular, the expression of N-WASP was 13-fold higher in LTs than in STs. This result confirms that the IGF-1/AKT/GSK3 $\beta / \mathrm{N}$-WASP signaling pathway influences the formation of adductor muscle and the control of movement in triploid oysters. GSK3 $\beta$ deactivated by IGF-1 increases glycogen synthesis by dephosphorylating glycogen synthase and increases protein synthesis by dephosphorylating eIF2B (Frame and Cohen 2001). It also increases myofibrillogenesis via the regulation of nebulin. In this study, we confirmed that GSK3 $\beta$ increases protein synthesis in triploid oysters and increases myofibrillogenesis via actin polymerization. In oysters such as $C$. angulata and C. gigas, GSK3 $\beta$ gene expression was reported to be high along with glycogen content in the adductor muscle at the time of gonad development (Zeng et al. 2013; Li et al. 2017). This stored energy is used for sexual maturity. However, in the case of triploid oysters, the stored energy of the adductor muscle appears to be important for increasing oyster size through protein synthesis and muscle formation.

On the other hand, the expression of PGC1 $\alpha$, which regulates the expression of FoxO and promotes protein degradation, was also higher in LTs compared with STs. This influenced the expression of troponin, another factor that acts on PGC1 $\alpha$ (Vescovo et al. 2005). Striated muscle contracts and relaxes by the action of myosin and actomyosin, a complex of actin-troponin-tropomyosin, and $\mathrm{Ca}^{2+}$ (Clark et al. 2002; Geeves and Holmes 1999; Gordon et al. 2000; Kuo and Ehrlich 2015). Troponin acts as a site for $\mathrm{Ca}^{2+}$ to bind actomyosin. Therefore, we suggested that the expression of LT was higher than that in ST, as well as muscle formation of muscle protein.

Taken together, these results indicate that growth of the adductor muscle of triploid oysters occurs by promoting the formation of muscle proteins through the IGF-1/AKT signaling pathway and inhibiting degradation. GSK3 $\beta$ and PGC1 $\alpha$ also affect muscle formation and movement (Fig. 6). 
In this study, it was examined how various factors affecting muscle growth, formation, and movement of the adductor muscle of triploid oysters vary with oyster size. Our results will improve our understanding of muscle growth, formation, and movement of triploid oysters via IGF-1/AKT signaling. We also confirmed that the adductor muscle of the triploid oyster affects the size of the oyster. The results of this study will be important for further studies investigating muscle growth of triploid oysters and marine mollusks.

\section{Conclusions}

Through the IGF-1/AKT signaling pathway, increased protein synthesis (mTOR/4EBP1 and p70S6K1; GSK3ß/ elF2B), inhibition of protein degradation (FoxO/MAFbx, MURF1, LC3), and activation of muscle-forming proteins (PGC1 $\alpha /$ troponin; GSK3 $\beta / \mathrm{N}-$ WASP) occur in the adductor muscle of triploid oysters. All of these processes affect the growth of triploid oysters, and activation of IGF-1/AKT signaling results in a larger size of the triploid oyster, C. gigas.

\section{Authors' contributions}

YHC contributed to the conceptualization, writing-review and editing, supervision, project administration, and funding acquisition. EYK contributed to the investigation, data analysis, and writing-original draft preparation. Both authors read and approved the final manuscript.

\section{Funding}

This research was supported by the Basic Science Research Program through the National Research Foundation of Korea (NRF) funded by the Ministry of Education (NRF-2016R1D1A1B03934914).

\section{Availability of data and materials}

All data sets generated during and/or analyzed during the current study are available from the authors on reasonable request.

\section{Ethics approval and consent to participate}

Not applicable

\section{Consent for publication}

Not applicable

\section{Competing interests}

The authors declare that they have no competing interests.

Received: 21 May 2019 Accepted: 20 August 2019

Published online: 06 September 2019

\section{References}

Allen SK. Flow cytometry: Assaying experimental polyploid fish and shellfish. Aquaculture. 1983;33:317-28.

Allen SK, Chew KK, Downing SL, Program WSG. Hatchery manual for producing triploid oysters. Seattle: University of Washington Press; 1989. p. 27.

Allen SK, Downing SL. Performance of triploid Pacific oysters, Crassostrea gigas (Thunberg). I. Survival, growth, glycogen content, and sexual maturation in yearlings. J Exp Mar Biol Ecol. 1986;102:197-208.

Alvarez-Tejado M, Naranjo-Suarez S, Jiménez C, Carrera AC, Landázuri MO, del Peso L. Hypoxia induces the activation of the Phosphatidylinositol 3-Kinase/ Akt cell survival pathway in PC12 cells: protective role in apoptosis. J Biol Chem. 2001;276:22368-74

Baxter RC, Martin JL, Beniac VA. High molecular weight insulin-like growth factor binding protein complex. Purification and properties of the acid-labile subunit from human serum. J Biologic Chem. 1989;264:11843-11848.
Buckway CK, Guevara-Aguirre J, Pratt KL, Burren CP, Rosenfeld RG. The IGF-I generation test revisited: a marker of GH sensitivity. J Clin Endocrinol Metab. 2001;86:5176-83.

Chapman RW, Mancia A, Beal M, Veloso A, Rathburn C, Blair A, Holland AF, Warr GW, Didinato G, Sokolova IM, Wirth EF, Duffy E, Sanger D. The transcriptomic responses of the eastern oyster, Crassostrea virginica, to environmental conditions. Mol Ecol. 2011;20:1431-49.

Clark KA, McElhinny AS, Beckerle MC, Gregorio CC. Striated muscle cytoarchitecture: an intricate web of form and function. Annu Rev Cell Dev Biol. 2002;18:637-706.

D'Ercole AJ, Stiles AD, Underwood LE. Tissue concentrations of somatomedin C further evidence for multiple sites of synthesis and paracrine or autocrine mechanisms of action. Proc Natl Acad Sci USA. 1984:81:935-9.

Frame S, Cohen P. GSK3 takes centre stage more than 20 years after its discovery. Biochem J. 2001:359:1-16.

Frick GP, Tai LR, Baumbach WR, Goodman HM. Tissue distribution, turnover, and glycosylation of the long and short growth hormone receptor isoforms in rat tissues. Endocrinol. 1998;139:2824-30.

Geeves MA, Holmes KC. Structural mechanism of muscle contraction. Annu Rev Biochem. 1999;68:687-728.

Glass DJ. PI3 kinase regulation of skeletal muscle hypertrophy and atrophy. Curr Top Microbiol Immunol. 2010;346:267-78.

Gordon AM, Homsher E, Regnier M. Regulation of contraction in striated muscle. Physiol Rev. 2000;80:853-924.

Gosteli-Peter M, Winterhalter KH, Schmid C, Froesch ER, Zapf J. Expression and regulation of insulin-like growth factor-I (IGF-I) and IGF-binding protein messenger ribonucleic acid levels in tissues of hypophysectomized rats infused with IGF-I and growth hormone. Endocrinol. 1994;135:2558-67.

Gricourt L, Bonnec G, Boujard D, Mathieu M, Kellner K. Insulin-like system and growth regulation in the Pacific oyster Crassostrea gigas: hrlGF-1 effect on protein synthesis of mantle edge cells and expression of an homologous insulin receptor-related receptor. Gen Comp Endocrinol. 2003:134:44-56.

Gricourt L, Mathieu M, Kellner K. An insulin-like system involved in the control of Pacific oyster Crassostrea gigas reproduction: hrlGF-1 effect on germinal cell proliferation and maturation associated with expression of an homologous insulin receptor-related receptor. Aquaculture. 2006:251:85-98.

Guevelou E, Huvet A, Sussarellu R, Milan M, Guo X, Li L, Zhang G, Quillien V, Daniel J, Quere C, Boudry P, Corporeau C. Regulation of a truncated isoform of AMP-activated protein kinase alpha (AMPKalpha) in response to hypoxia in the muscle of Pacific oyster Crassostrea gigas. J Comp Physiol B. 2013;183: $597-611$

Guo X, DeBrosse GA, Allen SK. All-triploid Pacific oysters (Crassostrea gigas Thunberg) produced by mating tetraploids and diploids. Aquaculture. 1996;142:149-61.

Hao S, Hou X, Wei L, Li J, Li Z, Wang X. Extraction and identification of the pigment in the adductor muscle scar of pacific oyster Crassostrea gigas. PLoS ONE. 2015;10:e0142439.

Hopkins AE. Activity of the adductor muscle in oysters. Physiol Zool. 1936;9: 498-507.

Jorgensen JOL, Jessen N, Pedersen SB, Vestergaard E, Gormsen L, Lund SA, Billestrup N. GH receptor signaling in skeletal muscle and adipose tissue in human subjects following exposure to an intravenous GH bolus. Am J Physiol Endocrinol Metabol. 2006;291:E899-905

Kim TR, Cho EW, Paik SG, Kim IG. Hypoxia-induced SM22alpha in A549 cells activates the IGF1R/PI3K/Akt pathway, conferring cellular resistance against chemo- and radiation therapy. FEBS Lett. 2012;586:303-9.

Kuo IY, Ehrlich BE. Signaling in muscle contraction. Cold Spring Harbor perspectives in biology. 2015;7:a006023.

Li B, Meng J, Li L, Liu S, Wang T, Zhang G. Identification and functional characterization of the glycogen synthesis related gene glycogenin in Pacific oysters (Crassostrea gigas). J Agric Food Chem. 2017;65:7764-73.

Mammucari C, Milan G, Romanello V, Masiero E, Rudolf R, Del Piccolo P, Burden SJ, Di Lisi R, Sandri C, Zhao J, Goldberg AL, Schiaffino S, Sandri M. FoxO3 controls autophagy in skeletal muscle in vivo. Cell Metabol. 2007;6:458-71.

Manning BD, Cantley LC. AKT/PKB signaling: navigating downstream. Cell. 2007; 129:1261-74

Miyazaki M, Esser KA. Cellular mechanisms regulating protein synthesis and skeletal muscle hypertrophy in animals. J Appli Physiol. 2009;106:1367-73.

Nell JA. Farming triploid oysters. Aquaculture. 2002;210:69-88.

Nell JA, Perkins B. Studies on triploid oysters in Australia: farming potential of triploid Pacific oysters, Crassostrea gigas (Thunberg), in Port Stephens, New South Wales, Australia. Aquacul Res. 2005;36:530-6. 
Parcellier A, Tintignac LA, Zhuravleva E, Hemmings BA. PKB and the mitochondria: AKTing on apoptosis. Cell Signal. 2008:20:21-30.

Rennie MJ, Wackerhage H, Spangenburg EE, Booth FW. Control of the size of the human muscle mass. Annu Rev Physiol. 2004;66:799-828.

Rommel C, Bodine SC, Clarke BA, Rossman R, Nunez L, Stitt TN, Yancopoulos GD, Glass DJ. Mediation of IGF-1-induced skeletal myotube hypertrophy by PI(3)K/Akt/mTOR and PI(3)KJAkt/GSK3 pathways. Nat. Cell Biol. 2001;3: 1009-13.

Sandri M. Signaling in muscle atrophy and hypertrophy. Physiology. 2008;23: 160-70.

Sarbassov DD, Guertin DA, Ali SM, Sabatini DM. Phosphorylation and regulation of Akt/PKB by the rictor-mTOR complex. Science. 2005;307:1098-101.

Schiaffino S, Dyar KA, Ciciliot S, Blaauw B, Sandri M. Mechanisms regulating skeletal muscle growth and atrophy. FEBS J. 2013;280:4294-314.

Schiaffino S, Mammucari C. Regulation of skeletal muscle growth by the IGF1Akt/PKB pathway: insights from genetic models. Skeletal Muscle. 2011;1:4.

Stanley JG, Allen SK Jr, Hidu H. Polyploidy induced in the American oyster, Crassostrea virginica, with cytochalasin B. Aquaculture. 1981;23:1-10.

Stitt TN, Drujan D, Clarke BA, Panaro F, Timofeyva Y, Kline WO, Gonzalez M, Yancopoulos GD, Glass DJ. The IGF-1/PI3K/Akt pathway prevents expression of muscle atrophy-induced ubiquitin ligases by inhibiting FOXO transcription factors. Mol Cell. 2004;14:395-403.

Takano K, Watanabe-Takano H, Suetsugu S, Kurita S, Tsujita K, Kimura S, Karatsu T, Takenawa T, Endo T. Nebulin and N-WASP cooperate to cause IGF-1-induced sarcomeric actin filament formation. Science. 2010;330:1536-40.

Velloso CP. Regulation of muscle mass by growth hormone and IGF-I. Br 」 Pharmacol. 2008;154:557-68.

Vescovo G, Ravara B, Gobbo V, Angelini A, Dalla Libera L. Skeletal muscle fibres synthesis in heart failure: role of PGC-1alpha, calcineurin and GH. Int J Cardiol. 2005;104:298-306

Xiao yan LI, Liu ZH, Cai RX. A study on scavenging activity of melanin to hydroxyl free radicals. J Sichuan Univ. 2003;40:1132-6.

Yu W, He C, Cai Z, Xu F, Wei L, Chen J, Jiang Q, Wei N, Li Z, Guo W, Wang X. A Preliminary study on the pattern, the physiological bases and the molecular mechanism of the adductor muscle scar pigmentation in pacific oyster Crassostrea gigas. Front Physiol. 2017;8:699.

Zeng Z, Ni J, Ke C. Expression of glycogen synthase (GYS) and glycogen synthase kinase 3beta (GSK3beta) of the Fujian oyster, Crassostrea angulata, in relation to glycogen content in gonad development. Com Biochem Physiol B. 2013; 166:203-14.

Zhang G, et al. The oyster genome reveals stress adaptation and complexity of shell formation. Nature. 2012:490:49-54.

\section{Publisher's Note}

Springer Nature remains neutral with regard to jurisdictional claims in published maps and institutional affiliations.

Ready to submit your research? Choose BMC and benefit from:

- fast, convenient online submission

- thorough peer review by experienced researchers in your field

- rapid publication on acceptance

- support for research data, including large and complex data types

- gold Open Access which fosters wider collaboration and increased citations

- maximum visibility for your research: over $100 \mathrm{M}$ website views per year

At BMC, research is always in progress.

Learn more biomedcentral.com/submissions 